\title{
The Use of Slang on The Headlines of Live Streaming E-Commerce
}

\author{
Yulian Dinihari ${ }^{1}$, Nur Indah Sari $^{2}$, Dian Nazelliana ${ }^{3}$ \\ \{yulian.dinihari@unindra.ac.id ${ }^{1}$,nur.indahsari@unnindra.co.id ${ }^{2}$,dian.nazelliana@unindra.ac.id ${ }^{3}$ \}
}

Universitas Indraprasta PGRI ${ }^{123}$

\begin{abstract}
This study aimed to determine the use of slang in the title of live streaming electronic commerce. The research method used was descriptive qualitative. The data used was written data that comes from the titles uploaded by online stores when they trade directly on social media. Data was sourced from electronic commerce Shopee and Facebook. There were 21 online shops that had titles using slang. This research resulted in 25 findings of slang language in the title, consisting of 3 slang terms on Facebook, and 22 slang terms on Shopee. The use of slang in the title of live streaming electronic commerce was closely related to abbreviations and acronyms and changes in phonological structure.
\end{abstract}

Keywords: Prokem Language, Headlines, E-Commerce.

\section{Penggunaan Bahasa Prokem pada Judul Siaran Langsung dalam Perdagangan Secara Elektronik}

\begin{abstract}
Abstrak. Penelitian ini bertujuan untuk mengetahui penggunaan bahasa prokem pada judul siaran langsung dalam perdagangan secara elektronik. Metode penelitian yang digunakan adalah deskriptif kualitatif. Data yang digunakan adalah data tulis yang berasal dari judul yang diunggah toko daring pada saat mereka melakukan perdagangan secara langsung pada media sosial. Data bersumber dari perdagangan elektronik Shopee dan Facebook. Terdapat 21 toko daring yang mempunyai judul menggunakaan bahasa prokem. Penelitian ini menghasilkan 25 temuan bahasa prokem yang terdapat pada judul, terdiri atas 3 bahasa prokem pada Facebook, dan 22 bahasa prokem pada Shopee. Penggunaan bahasa prokem pada judul siaran langsung dalam perdagangan secara elektronik sangat berkaitan dengan singkatan dan akronim dan perubahan struktur fonologis.
\end{abstract}

Kata kunci: Bahasa Prokem, Tajuk, Perdagangan Elektronik.

\section{Pendahuluan}

Di tengah situasi merebaknya pandemi virus Covid-19 mengharuskan masyarakat melakukan kegiatannya di rumah dan menjaga jarak sosial (social distancing) sesuai dengan anjuran pemerintah. Perkembangan teknologi informasi yang pesat mengakibatkan peningkatan aktivitas bisnis yang pesat pula terutama dalam bidang perdagangan. 
Implementasi teknologi informasi dalam bidang perdagangan melahirkan sarana jual beli baru yang dikenal dengan perdagangan elektronik [1]. perdagangan elektronik merupakan tipe perdagangan yang memanfaatkan internet sebagai media transaksi. perdagangan elektronik adalah kegiatan-kegiatan bisnis dengan tujuan mengambil keuntungan seperti penjualan, pembelian, pelayanan, informasi, dan perdagangan melalui perantara yaitu melalui suatu jaringan komputer, terutama internet. Dengan adanya Ecommerce ini memudahkan costumer untuk dapat melakukan transaksi jual beli tanpa harus datang ke tempatnya [2]. Layanan perdagangan elektronik semakin banyak yang bermunculan dan populer dengan cepat.

Pangsa pasar yang sangat besar, banyak penyedia layanan perdagangan elektronik ini berlomba-lomba untuk menjadi yang terdepan. Persaingan di antara penyedia layanan perdagangan elektronik pun secara tidak langsung semakin ketat [3]. perdagangan elektronik bermodel C2C (Consumer to Consumer) menyediakan jalan untuk konsumen menjual barang kepada konsumen lainya. Consumer to Consumer melibatkan pertukaran informasi melalui forum internet yang menarik bagi kelompok minat khusus tertentu [4]. Strategi yang dipilih perdagangan elektronik dalam pemanfaatan mengadopsi fitur sosial media dalam penerapannya seperti fitur time line, follow, pencarian, fitur bintang untuk rekomendasi, live chat, game, dan live streaming [5]. Live streaming memudahkan para penjual dan pembeli dalam berinteraksi melalui fitur live chatnya [6]. Pembeli dan penjual bisa langsung berinteraksi dalam berkomunikasi.

Komunikasi sebagai media transmisi dalam penyampaian pesan merupakan aspek penting dan kompleks bagi kehidupan manusia. Bahasa merupakan salah satu bentuk penyampaian dalam perdagangan. Pengaruh arus globalisasi ini termasuk di dalamnya pendidikan, kebudayaan (termasuk di dalamnya bahasa), dan ekonomi yang sering mengutamakan penggunaan bahasa asing daripada bahasa Indonesia. Seperti halnya bahasa gaul atau bahasa prokem yang disebut juga sebagai bahasa prokem merupakan bentuk ragam bahasa dari bahasa nonformal yang digemari pemakai bahasa [7]. Kalangan generasi muda yang menggunakan bahasa prokem dianggap modern dan eksistensinya sangat diapresiasi dari kalangan mereka sendiri [8]. Dengan perkembangan zaman munculah ragam-ragam bahasa yang dihasilkan oleh kreativitas manusia [9].

Selain itu, penggunaan bahasa prokem di Indonesia merupakan suatu hal yang unik dan kreatif karena memiliki bentuk kosakata yang sangat bervariasi dengan jumlah yang cukup banyak. Bahasa prokem juga digunakan sebagai bentuk pernyataan seorang sebagai anggota kelompok masyarakat yang berbeda dari kelompok yang lain. Dengan hadirnya bahasa prokem yang berkembang pada saat ini dianggap sesuatu yang wajar karena sesuai dengan perkembangan usia remaja dan penggunaan bahasa prokem pun pada kalangan kelompok usia tertentu dan bersifat tidak resmi. Jika mereka berada di luar lingkungan kelompoknya, mereka akan menggunaan bahasa yang berlaku secara umum di lingkungan masyarakat tempat mereka berada dan jarang sekali yang tetap menggunakan bahasa prokem seperti di dalam kelompoknya. Bahasa prokem diciptakan melalui perubahan bentuk pesan Linguistik tanpa mengubah isinya untuk maksud penyembunyian atau kejenakaan. Jadi bahasa prokem hanya sebuah transformasi sebagian dari suatu bahasa menurut pola-pola tertentu. Bahasa berkembang maju secara perlahan sebagaimana manusia yang terus menurut mengalami perkembangan [8]

Bahasa tersebut dianggap lebih menarik perhatian para market muda di kalangan milenial sekarang ini. Maka dari itu peneliti tertarik untuk mengetahui penggunaan bahasa prokem yang digunakan dalam judul toko daring pada saat mereka menyiarkan secara langsung dagangannya lewat perdagangan elektronik. Para generasi muda mengkreasikan bahasa- 
bahasa dalam strategi pemasaran mereka karena dianggap modern oleh sesama generasi muda. Sehingga mereka berlomba-lomba untuk menunjukkan eksistensi mereka. Berdasarkan hal di atas peneliti tertarik untuk menggunakan perdagangan elektronik sebagai objek pada penelitian ini dan bahasa prokem menjadi hal yang ingin dianalisis oleh peneliti.

\section{Metode}

Besarnya jumlah penggunaan bahasa Indonesia (populasi) dalam media sosial line, facebook, whatsapp, dan instagram menyebabkan data diambil secara sampling. Teknik sampling yang digunakan adalah sample random sampling, yaitu pengambilan sampel secara acak tanpa memperhatikan strata yang ada dalam populasi [10]. Data dikumpulkan dengan metode simak yang dibantu dengan teknik lanjutan berupa teknik catat. Menurut Mahsun metode simak dapat disejajarkan dengan metode pengamatan atau observasi dalam ilmu sosial, khususnya antropologi [11].

Penelitian ini diolah menggunakan jenis metode deskriptif kualitatif. Metode deskriptif kualitatif bertujuan untuk mendeskripsikan, menjelaskan, menganalisis permasalahan yang akan diteliti. Dengan metode ini, data yang telah dikumpulkan berupa penggunaan bahasa Indonesia pada perdagangan elektronik, instagram, Shoppe, dan Facebook yang melakukan perdagangan secara langsung dalam media. Dideskripsikan secara lengkap sehingga mendapatkan suatu simpulan mengenai penggunaan bahasa prokem pada perdagangan elektronik, instagram, Shoppe, dan Facebook yang melakukan perdagangan secara langsung.

\section{Hasil dan Pembahasan}

Berdasarkan dari penelitian yang dilakukan melalui pengamatan oleh peneliti pada siaran langsung perdagangan elektronik di Shoppe, Facebook, dan instagram. Terdapat penggunaan bahasa prokem di dalam judul pada siaran langsung perdagangan elektronik tersebut. Peneliti telah menemukan kurang lebih, pada tabel 1 berikut.

Tabel 1. Data Bahasa Prokem dalam Judul Siaran Langsung Toko Daring

\begin{tabular}{llll}
\hline No & Bahasa Prokem dalam Judul & Sumber Media & Bentuk Baku \\
\hline 1. & Santuy & Shopee & Santai \\
2. & PL & Shopee & Bekas \\
3. & Nyok & Shopee & Ayo \\
4. & Gercepan & Shopee & Gerak cepat \\
5. & Emejing & Shopee & Menakjubkan \\
6. & Cin & Shopee & Cinta \\
7. & KUYYYYY & Shopee & Ayo \\
8. & Gaskeun & Shopee & Berjalan terus \\
9. & Mehong & Shopee & Mahal \\
10. & Gabut & Shopee & Tidak ada kerjaan \\
11. & Oleng & Shopee & Terombang-ambing \\
12. & Ngoblak & Shopee & Mengaduk \\
13. & Ambyar & Shopee & Bertebaran \\
14. & Murmer & Shopee & Murah meriah \\
15. & Syantik & Shopee & Cantik
\end{tabular}




\begin{tabular}{llll} 
16. & Harga miring & Shopee & Harga lebih murah \\
17. & Kepoinn & Shopee & Penasaran \\
18. & Ciwi & Shopee & Perempuan \\
19. & Say & Shopee & Sayang \\
20. & PHP & Shopee & Pemberi harapan palsu \\
21. & Gaess & Shopee & Kawan \\
22. & Yuks & Shopee & Ayo \\
23. & Zheyenk & Facebook & Sayang \\
24. & Murce & Facebook & Murah sekali \\
25. & Anjlog & Facebook & Anjlok \\
\hline
\end{tabular}



Gambar 1. Data 1

Berdasarkan data 1 di atas terdapat judul dari toko daring "PAPA_MBUL Thrifting Store" yang sedang melakukan siaran langsung di Shoppe dengan jumlah 21 penonton pada Selasa, 20 Oktober 2020. Dalam judul tersebut terdapat dua penggunaan bahasa prokem. Pertama kata "Santuy" dalam bentuk bahasa bakunya adalah santai yang berarti dalam keadaan bebas dan senggang. Kata santuy tersebut digunakan oleh penjual karena dinilai sebagai bahasa yang bisa menarik pelanggan untuk bersama-sama dengan jiwa yang bebas menonton siaran langsung tersebut dan tidak lupa membelinya. Kemudian bahasa prokem kedua dalam judul tersebut adalah terdapat singkatan " $P L$ " singkatan dari preloved dalam bahasa Indonesia artinya bekas dan mempunyai makna sudah pernah dipakai. Singkatan PL di atas memang lazim digunakan para penjual agar menciptakan hal yang mudah untuk dibaca karena hanya menggunakan singkatan yang penonton sudah paham untuk melihat baju bekas yang dijual oleh toko tersebut.

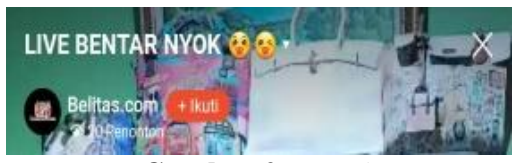

Gambar 2. Data 2

Berdasarkan data 2 di atas terdapat judul dari toko daring "Belitas.com" yang sedang melakukan siaran langsung di Shoppe dengan jumlah 20 penonton pada Selasa, 20 Oktober 2020. Terdapat kata dalam judul yang menggunakan bahasa prokem yaitu kata "nyok", persamaan katanya adalah ayo atau maknanya adalah mengajak pembeli untuk melihat dagangannya. Kata nyok berasal dari bahasa Betawi. Kata tersebut biasa digunakan sebagai kata yang dikenal lebih akrab jika digunakan dalam komunikasi lisan sehari-hari.

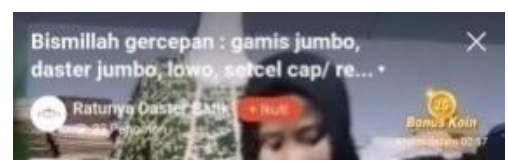

Gambar 3. Data 3 
Berdasarkan data 3 di atas terdapat judul dari toko daring "Ratunya Daster Batik" yang sedang melakukan siaran langsung di Shoppe dengan jumlah 23 penonton pada Selasa, 20 Oktober 2020. Dalam judul terdapat dua kata yang menggunakan bahasa prokem yaitu pertama kata gercepan yang merupakan akronim dari gerak cepat dan diberikan konfiks -an yang bukan merupakan afiks baku. Gerak cepat di sana mengartikan bahwa penjual menginginkan penonton siaran langsung untuk segera membeli dagangannya. Kata kedua adalah "Setcel" yang merupakan akronim dari setelan celana. Setelan celana di sana mengartikan bahwa mereka menjual satu kesatuan baju dengan celananya. Bahasa ini umum digunakan untuk beberapa toko daring. Namun sebagian calon pembeli pasti akan kesulitan untuk mengartikannya.

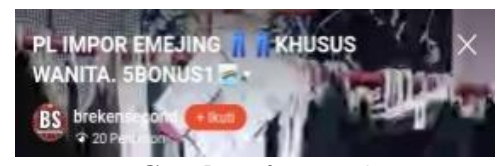

Gambar 4. Data 4

Berdasarkan data 4 di atas terdapat judul dari toko daring "Brekensecond" yang sedang melakukan siaran langsung di Shoppe dengan jumlah 20 penonton pada Selasa, 20 Oktober 2020. Dalam judul siaran langsung toko daring terdapat kata "Emejing" yang merupakan salah satu bahasa prokem. Kata emejing merupakan modifikasi dari bahasa Inggris yaitu amazing yang artinya menakjubkan. Adanya perubahan fonem /a/ menjadi /e/ dan fonem /z/ menjadi /j/



Gambar 5. Data 5

Berdasarkan data 5 di atas terdapat judul dari toko daring "Suplayer Baju Import Termurah" yang sedang melakukan siaran langsung di Shoppe dengan jumlah 20 penonton pada Selasa, 20 Oktober 2020. Dalam judul tersebut terdapat kata "Murce" dan "Cin" yang merupakan bahasa prokem. Murce adalah akronim tidak baku dari murah cekali adanya perubahan fonem /s/ menjadi /c/ pada kata cekali. Kata Cin merupakan kependekan dari kata cinta. Pada kata cinta di sini bukan arti sebenarnya, melainkan hanya kata sapaan yang dapat digunakan untuk kesan yang lebih akrab. Hal ini dimaksud agar si penonton atau calon pembeli lebih tertarik pada toko daringnya.

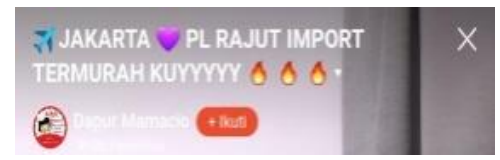

Gambar 6. Data 6

Berdasarkan data 6 di atas terdapat judul dari toko daring "Dapur Mamacio" yang sedang melakukan siaran langsung di Shoppe dengan jumlah 26 penonton pada Selasa, 20 Oktober 2020. Berdasarkan judul di atas terdapat kata " $K U Y Y Y Y Y$ " yang merupakan bagian dari bahasa prokem. Kuy adalah kata tidak baku yang sama maknanya dengan kata ayo. Berasal dari kebalikannya yaitu yuk atau ayo. Orang menggunakan kata yuk karena dianggap lebih 
sederhana dan fleksibel dibanding kata ayo. Intinya mengajak penonton untuk membeli produk yang dijual toko daring Dapur Mamacio.



Gambar 7. Data 7

Berdasarkan data 7 di atas terdapat judul dari toko daring "Zackitchen" yang sedang melakukan siaran langsung di Shoppe dengan jumlah 26 penonton pada Selasa, 20 Oktober 2020. Berdasarkan data 7 di atas terdapat kata "Gaskeun" yang sama artinya dengan berjalan terus atau segera. Bahasa ini interferensi dari bahasa Sunda. Akhiran keun merupakan dialek yang biasa digunakan sebagai bahasa keakraban di daerah Jawa Barat.

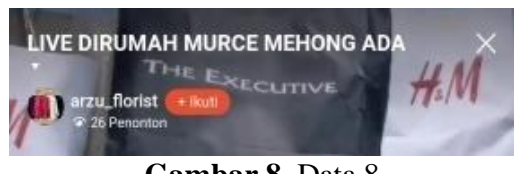

Gambar 8. Data 8

Berdasarkan data 8 di atas terdapat judul dari toko daring "arzu_florist" yang sedang melakukan siaran langsung di Shoppe dengan jumlah 26 penonton pada Selasa, 20 Oktober 2020. Terdapat kata "MEHONG" yang mempunyai arti mahal. Mehong merupakan bahasa prokem yang berdasarkan dari analisis morfologisnya terdapat banyak perubahan fonem. Perubahan fonem /a/ menjadi /e/, perubahan fonem /a/ menjadi /o/, dan perubahan fonem /l/ menjadi /ng/. Kata mehong diperkenalkan semenjak adanya bahasa banci atau transgender pada tahun 1997.

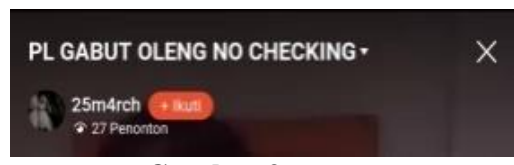

Gambar 9. Data 9

Berdasarkan data 9 di atas terdapat judul dari toko daring " $25 \mathrm{~m} 4 \mathrm{rch}$ " yang sedang melakukan siaran langsung di Shoppe dengan jumlah 27 penonton pada Selasa, 20 Oktober 2020. Berdasarkan data 9 di atas terdapat dua kata yang merupakan bagian dari bahasa prokem yaitu kata "GABUT" dan "OLENG". Gabut memiliki arti tidak mempunyai kerjaan, sedangkan kata oleng mempunyai arti baku menurut KBBI daring yaitu terombang-ambing. Padahal maksud dari penjual di sini adalah oleng yaitu harganya lebih murah dibanding toko lain.

Data 10

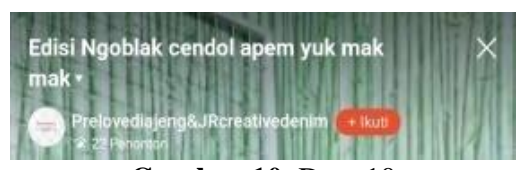

Gambar 10. Data 10

Berdasarkan data 10 di atas terdapat judul dari toko daring "Prelovediajeng\&JRcreativedenim" yang sedang melakukan siaran langsung di Shoppe 
dengan jumlah 22 penonton pada Selasa, 20 Oktober 2020. Dalam data 10 di atas terdapat kata "Ngoblak" dalam bahasa prokem ngoblak mempunyai arti mencari-cari atau mengaduk sesuatu barang sampai mendasar dan berantakan. Ngoblak dengan aduk merupakan suatu hal yang hampir mirip, tetapi jauh perbedaannya. Dalam kata ngoblak terdapat kiasan makna yang lebih negatif dibanding kata aduk. Sehingga penjual merasa kata ngoblak digunakan untuk judul pada siarang langsung tokonya agar orang lebih tertarik.



Berdasarkan data 11 di atas terdapat judul dari toko daring "dian_chaya" yang sedang melakukan siaran langsung di Shoppe dengan jumlah 30 penonton pada Selasa, 20 Oktober 2020. kata "AMBYAR" merupakan kata yang fenomenal akhir-akhir ini. Kata ambyar pertama kali masuk ke KBBI Edisi kedua tahun 1991. Dengan label bahasa Jawa dan ragam cakapan. Kata ambyar sama dengan kata bertebaran, berpisah-pisah, dan tidak terkonsentrasi lagi. Dalam kata bertebaran di sini bukan artinya barang dijual disebar-sebarkan dan berpisah, tetapi penjual ingin memberi tahu bahwa pemandu acara dari toko daring tersebut merupakan orang yang sedang patah hati, hatinya sedang berserakan karena patah.

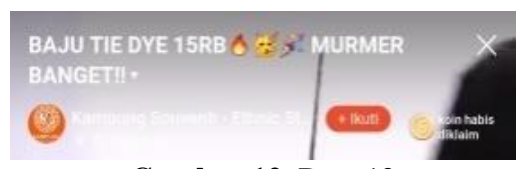

Gambar 12. Data 12

Berdasarkan data 12 di atas terdapat judul dari toko daring "Kampung Souvenir - Ethnic St" yang sedang melakukan siaran langsung di Shoppe dengan jumlah 20 penonton pada Selasa, 20 Oktober 2020. Kata "MURMER" merupakan akronim dari kata murah meriah. Analisis secara semantik mengartikan kata murmer adalah sama dengan murah meriah yang memiliki arti sangat murah. Penjual ingin menyampaikan bahwa baju yang dijualnya paling murah di antara toko lainnya.

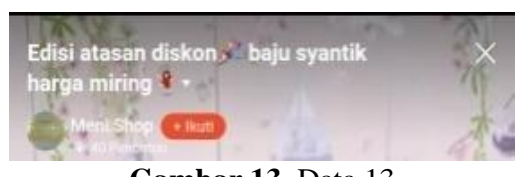

Gambar 13. Data 13

Berdasarkan data 13 di atas terdapat judul dari toko daring "Meni.Shop" yang sedang melakukan siaran langsung di Shoppe dengan jumlah 40 penonton pada Selasa, 20 Oktober 2020. Berdasarkan dara 13 di atas terdapat dua kata yang merupakan bagian dari bahasa prokem yang pertama adalah kata "syantik" yang berarti cantik dan "harga miring" yang memiliki arti harnya lebih murah. Kata syantik terjadinya perubahan fonem /c/ menjadi /sy/ kata tersebut pertama dipopulerkan oleh penyanyi Syahrini yang biasa menggunakan kata dengan banyak menggunakan pelemahan fonem agar terkesan lebih akrab dan lebih manja apabila didengar atau dibaca. Kata yang kedua adalah harga miring, ini merupakan bagian 
dari klausa yang artinya adalah harga lebih murah. Istilah tersebut biasa digunakan oleh pemandu acara dalam kondisi informal dan dianggap menjadi suatu kata yang mudah didengar dibanding kata aslinya atau bentuk bakunya.

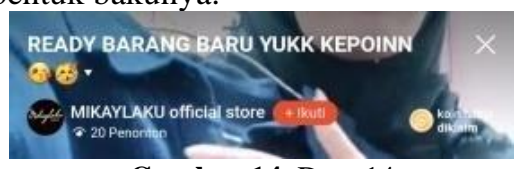

Gambar 14. Data 14

Berdasarkan data 14 di atas terdapat judul dari toko daring "MIKAYLAKU official store" yang sedang melakukan siaran langsung di Shoppe dengan jumlah 20 penonton pada Selasa, 20 Oktober 2020. Berdasarkan data di atas terdapat kata "KEPOINN" yang mempunyai dasar kata kepo dan penambahan akhiran tidak baku -an. Kepo mempunyai arti atau persamaan arti dengan kata penasaran. Namun penambahan akhiran tidak baku -an menjadikan kata kepoin memiliki arti yang beda. Kepoin di sini merupakan satu kesatuan yang mempunyai arti dicari tahu lebih dalam lagi tentang suatu barang yang sedang ditawarkan tersebut baik dari segi kualitas, harga, dan keunggulan dibanding toko daring lain.

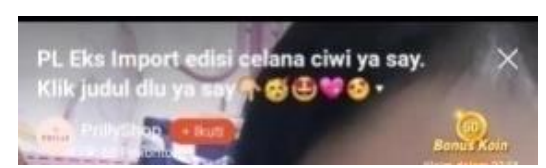

Gambar 15. Data 15

Berdasarkan data 15 di atas terdapat judul dari toko daring "PrillyShop" yang sedang melakukan siaran langsung di Shoppe dengan jumlah 60 penonton pada Selasa, 20 Oktober 2020. Berdasarkan data di atas terdapat dua kata yang merupakan kategori bahasa prokem. Pertama adalah kata "Ciwi" yang memilki persamaan arti dari kata cewe atau perempuan. Analisis kebahasaan dilihat dari perubahan fonem /e/ menjadi /i/. Kata kedua adalah "Say" kata tersebut adalah kependekan dari kata sayang yang merupakan panggilan akrab atau kata sapaan agar pembeli lebih lunak karena kebaikan hati seseorang yang menyayangi.



Gambar 16. Data 16

Berdasarkan data 16 di atas terdapat judul dari toko daring "wancollections" yang sedang melakukan siaran langsung di Shoppe dengan jumlah 133 penonton pada Selasa, 20 Oktober 2020. Pada kata tersebut terdapat bahasa prokem yaitu "PHP" singkatannya adalah pemberi harapan palsu. Artinya penjual tidak ingin ada calon pembeli yang memberikan perhatian terhadap dagangannya secara berlebih, tetapi pada ujungnya mereka tidak jadi membeli karena beberapa alasan. Biasanya kata $P H P$ merupakan kata yang digunakan untuk melakukan interupsi agar lawannya tidak melakukan hal demikian.

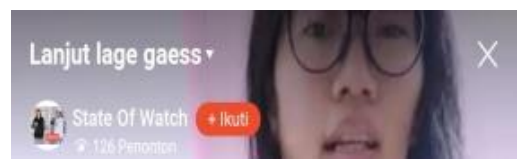

Gambar 17. Data 17 
Berdasarkan data 17 di atas terdapat judul dari toko daring "State Of Watch" yang sedang melakukan siaran langsung di Shoppe dengan jumlah 126 penonton pada Selasa, 20 Oktober 2020. Berdasarkan judul di atas terdapat satu kata yaitu "gaess" yang mempunyai arti dalam bahasa Inggris adalah orang dalam bentuk jamak. Pada era digital sekarang banyak sekali penggunaan kata gaess untuk menjadikan salah satu kata sapaan atau panggilan bagi yang menonton. Kata gaess di sini dari bentuk asalnya yaitu kata guys dalam bahasa Inggris.

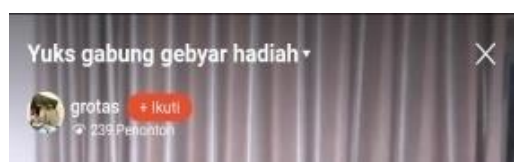

Gambar 18. Data 18

Berdasarkan data 18 di atas terdapat judul dari toko daring "grotas" yang sedang melakukan siaran langsung di Shoppe dengan jumlah 239 penonton pada Selasa, 20 Oktober 2020. Terdapat kata "Yuks" yang merupakan bagian dari bahasa prokem persamaan katanya adalah ayo atau maknanya adalah mengajak pembeli untuk melihat dagangannya. Kata yuks biasa digunakan untuk perbincangan yang lebih akrab. Dalam kategori informal kata ini dianggap lebih efektif dari penyebutan kata ayo.

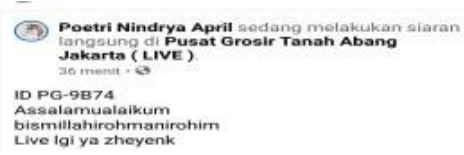

Gambar 19. Data 19

Berdasarkan data 19 di atas terdapat judul dari toko daring "Poetri Nindrya April" yang sedang melakukan siaran langsung di media sosial Facebook pada Selasa, 20 Oktober 2020. Berdasarkan analisi data 19 di atas terdapat kata "zheyenk" yang merupakan bagian dari bahasa prokem. Kata zheyenk mempunyai bentuk awal sayang. Sayang di sini bukan arti sebenarnya, kata sayang di sini hanya sebagai panggilan atau sapaan yang lebih mengakrabkan baik ke sesama perempuan atau ke lawan pasangannya.

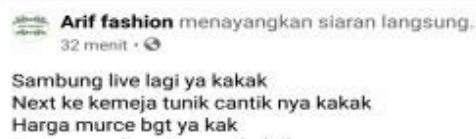

Gambar 20. Data 20

Berdasarkan data 20 di atas terdapat judul dari toko daring "Arif fashion" yang sedang melakukan siaran langsung di media sosial Facebook pada Selasa, 20 Oktober 2020. Terdapat kata "murce" yang merupakan bagian dari bahasa prokem. Murce adalah akronim tidak baku dari murah cekali adanya perubahan fonem /s/ menjadi /c/ pada kata cekali. Murce biasa didengar dari kalangan milenial untuk menyingkat kata.

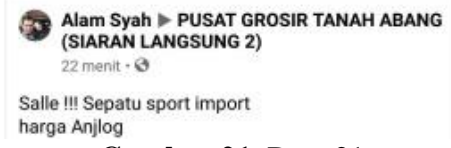

Gambar 21. Data 21 
Berdasarkan data 21 di atas terdapat judul dari toko daring "Alam Syah" yang sedang melakukan siaran langsung di media sosial Facebook pada Selasa, 20 Oktober 2020. Berdasarkan data 21 terdapat satu kata "Anjlog" yang merupakan bahasa prokem. Anjlog adalah perubahan dari kata anjlok atau jatuh. Anjlog di sini mengartikan harganya lebih murah dibanding toko daring lain yang dijual di media sosial facebook.

Hasil penelitian ditemukan terdapat sebanyak 25 temuan bahasa prokem yang terdapat dalam judul pada saat pedagang menjajakan dagangannya secara langsung pada media sosial facebook sebanyak 3 bahasa prokem, dan 22 bahasa prokem dalam shoppe. Penggunaan bahasa prokem dalam proses pembentukannya melalui cara semantik, proses morfologis, tambahan pemberian suatu sisipan tidak baku, dan pemendekan kata. Sementara itu, arti atau makna yang terkandung masih dapat dimengerti oleh bicaranya.

Dalam pelaku ekonomi penggunaan bahasa prokem tidak bisa dihindari, karena biasanya digunakan untuk berkomunikasi di lingkungan sosial dan juga termasuk variasi bahasa Indonesia yang ada saat ini. Adanya bahasa ini dianggap salah satu strategi dalam menggaet calon pembeli agar lebih tertarik dengan dagangan yang akan dipertontonkan. Namun pada saat ini, banyak remaja yang tidak memakai bahasa Indonesia yang baik dan benar dan mereka lebih gemar untuk menggunakan bahasa prokem ketika mereka berkomunikasi satu sama lain. Terdapat beberapa dampak yang muncul dari penggunaan bahasa prokem itu sendiri, yaitu : a. Bahasa prokem jika pemakaiannya tidak disesuaikan dengan situasi dan kondisi akan mempersulit proses berkomunikasi jika lawan bicara tidak mengerti bahasa tersebut. b. Bahasa prokem dapat menyebabkan penurunan kualitas penggunaan bahasa Indonesia di kalangan remaja pada saat ini maupun dimasa yang akan datang, karena mereka terbiasa menggunakan bahasa prokem sehingga mereka lupa tentang penggunaan bahasa Indonesia yang baik dan benar. c. Penggunaan bahasa prokem secara terus menerus, dapat menggeser eksistensi bahasa Indonesia jika ini tidak segera disadari.

Bahasa prokem atau yang lebih dikenal sebagai bahasa prokem memiliki sifat informal serta tidak dapat digunakan dalam acara formal atau resmi yang membutuhkan penggunaan bahasa Indonesia yang baik dan benar. Pada saat ini bahasa prokem merupakan bahasa yang secara tidak langsung dapat mengubah tata bahasa Indonesia. Jika hal ini terus berlangsung, penggunaan bahasa prokem yang lebih mendominasi daripada penggunaan bahasa Indonesia baku. Tentu saja hal tersebut dapat menimbulkan kekhawatiran kita sebagai bangsa Indonesia, karena kaum pelaku ekonomi merupakan bagian dari pengguna bahasa dan para penerus bangsa di masa yang akan datang. Jika mereka tidak mengenali atau mengetahui penggunaan bahasa Indonesia yang baik dan benar bukan tidak mungkin penutur bahasa Indonesia akan bekurang suatu saat nanti. Oleh karena itu kesadaran masyarakat harus dibuka lebih lebar lagi agar mereka dapat mengutamakan penggunaan bahasa Indonesia dan menggunakan bahasa prokem sesuai dengan situasi dan kondisinya. Jangan sampai bahasa prokem lebih mendominasi penggunaannya daripada bahasa Indonesia, karena bahasa Indonesia merupakan identitas bangsa Indonesia. Kesadaran tersebut harus kita tanam mulai dari diri kita sendiri, sehingga dapat menular dan berkembang ke masyarakat luas.

\section{Simpulan}

Dalam strategi penjualan sebuah bahasa memang salah satu strategi yang harus dilakukan untuk para penjual dalam mempromosikan barang dagangannya tersebut. Bahasa prokem yang 
digunakan pada judul toko daring dalam perdagangan elektronik tidak perlu dikhawatirkan, karena hal tersebut tidak akan menjadi ancaman bagi bahasa Indonesia secara luas. Penggunaan bahasa prokem yang disisipkan dalam judul toko daring tersebut adalah hanya salah satu cara untuk membuat komunikasi menjadi semakin cepat dan sederhana. Kemudian penjual melakukan hal tersebut karena bagian dari strategi mereka dalam menarik perhatian pembeli pada umumnya. Dalam penelitian bahasa prokem pada judul toko daring yang melakukan siaran langsung pada saat mempromosikan dagangannya. Terdapat dua perdagangan elektronik yang judul dari toko daringnya menggunakan bahasa prokem yaitu Shopee dan Facebook. Penggunaan bahasa prokem dalam proses pembentukannya melalui cara semantik, proses morfologis, tambahan pemberian suatu sisipan tidak baku, dan pemendekan kata. Sementara itu, arti atau makna yang terkandung masih dapat dimengerti oleh bicaranya. Bahasa prokem biasanya digunakan untuk berkomunikasi dengan teman sebaya atau berada di lingkungan yang mengetahui arti dan makna dari bahasa prokem tersebut..

\section{Referensi}

[1] Adhy S. Implementasi E-Commerce B2C Bahasa Jawa untuk UMKM Jolali KaoSemarang. J. Masy. Inform., 2015.

[2] Rejeki RSA, Utomo AP. Perancangan dan Pengaplikasian Sistem Penjualan pada ‘ Distro Smith ’ Berbasis E - Commerce. J. Teknol. Inf. Din., 2011.

[3] Felita P, Oktivera E. Pengaruh Sales Promotion Shopee Indonesia Terhadap Impulsive Buying Konsumen Studi Kasus: Impulsive Buying Pada Mahasiswa STIKS Tarakanita. J. Ilmu Komunikasi dan Bisnis, 2019.

[4] Prayoga AF, Priyadi Y, Dharmoputro S. Pengaruh Fitur Chatting Dan Tawar Pada Aplikasi Shopee Terhadap Kepuasan Pelanggan. E-Proceeding Manag. 2016.

[5] Suswanto P, Setiawati SD. Strategi Komunikasi Pemasaran Shopee Dalam Membangun Positioning Di Tengah Pandemi Covid-19 Di Indonesia. Linimasa J. Ilmu Komunikasi. 2020.

[6] Pratama A. Pengaruh Youtube Advertising Terhadap Respons Konsumen," Inter Community. J. Communication. Empower. 2019.

[7] Setyawati N. Pemakaian Bahasa Gaul Dalam Komunikasi Di Jejaring Sosial. Pemakaian Bhs. Gaul Dalam Komun. Di Jejaring Sos., 2016.

[8] Putra AS, Hartanto BH. Penggunaan Bahasa Prokem Pada Media Sosial Whats App Mahasiswa Universitas Muhammadiyah Tangerang. Ling. Rima J. Pendidik. Bhs. dan Sastra Indones. 2020.

[9] Istiqomah DS, Nugraha V. Analisis penggunaan bahasa prokem pada media sosial. J. Parol. 2018.

[10] S. (2016: 118). Metode Penelitian. 2016.

[11] Mahsun M. Metode Penelitian Bahasa: Tahapan, Strategi, dan Tekniknya. 2014. 